\title{
Genetic mutation in mangrove Acanthus ilifolicius base on DNA Barcode (rbcL and matK gen) in the different environment change in coastal Cilacap, Central Java, Indonesia
}

\author{
${ }^{1 *}$ R. Taufan Harisam, ${ }^{1)}$ Florencius Eko Dwi Haryono, ${ }^{1)}$ Bintang Marhaeni, ${ }^{1)}$ Norman Arie Prayogo, ${ }^{1)}$ Petrus \\ Hary Tjahja Soedibya \\ ${ }^{1 *}$ Fisheries and Marine Science Faculty, Jenderal Soedirman University, Indonesia
}

\begin{abstract}
. mangroves are salt-tolerant forest ecosystems of tropical and subtropical intertidal regions. They are among most productive, diverse, biologically important ecosystem and inclined toward the threatened system. In recent years, DNA barcoding using plastid markers $r b c L$ and matKhas been suggested as an effective method to enrich traditional taxonomic expertise for rapid species identification, mutation genetic and biodiversity inventories. This research use survey method and descriptive qualitative analysis in the laboratory.This research aimed to determine the mutation DNA of plant barcoding standard $A$. Ilifolicius based gene $r b c L$ and matK compare with species in the different location. Total DNA was isolated and successfully amplified by the Polymerase Chain Reaction (PCR) using primers based on the gene $r b c L$ and matK. The results of sequencing long DNA fragments showed $760 \mathrm{bp}$ are amplified by the forward primer and bp were 760 bp amplified by the primer for reverse. This study indicated that had been a mutation spesies in contaminated mangroves compared with uncontaminated mangroves.
\end{abstract}

\section{Introduction}

The coastal wetlands of the tropics and the subtropics of the world are characterised by the presence of a unique group of plant species, the mangroves. Mangroves are exist along the sheltered inter-tidal coastline, in the margin between the land and sea in tropical and subtropical areas. This ecosystem endowed with productive wetland having flora and fauna adapted to local environment such as fluctuated salinity, anoxic condition, and water level [31]. They are most productive and biologically important ecosystems of the world which provide goods and services to human society in marine and coastal systems [25]. They have unique features such as aerial breathing roots, extensive supporting roots, buttresses, salt-excreting leaves and viviparous propagules [11],[34].

The genus Acanthus has mangroves species i.e. A. Ilifolicius in mangroves all over the world. The genus Acanthus L. belonging to the family Acanthaceae is an Old World genus native of tropics and subtropics with about 30 species. It is often distinguished from the related genera by spiny leaves, spicate terminal inflorescences, two bracteoles and uniform anthers [11]. Four species A. ilifolicius, A. Ilicifolius L., A. volubilis Wall. and A. xiamenensis are known from mangrove communities and are classified as true mangrove species [28]. Of these A. xiamenensis is endemic to China and all the other species are common in Indo West Pacific (IWP) region. However, the taxonomical identity of A. xiamenensis in China is not clear; treated A. xiamenensis and A.ilicifolius as the same species [37]. Today they are threatened by high rates of anthropogenic disturbance, including habitat destruction, pollution, fragmentation, and changes in oceanic and estuarine environments due to climate change [36], [1], [10].

DNA barcoding appears to be a promising approach for taxonomic identification, characterization, and discovery of newer species, facilitating biodiversity studies [17]. It helps researchers to appreciate genetic and evolutionary associations by collection of molecular, morphological, and distributional data [17]. DNA barcoding is currently used effective tool that enables rapid and accurate identification of plant [22]. The Consortium for the Barcode of Life (CBOL) recommended $r b c L+m a t K$ as the core barcode. However, these core barcode further combined with the $p s b \mathrm{~A}-\operatorname{trn} \mathrm{H}$ intergenic non-coding spacer region whichimproved discrimination power of core barcode. The noncoding intergenic region $p s b \mathrm{~A}-t r n \mathrm{H}$ exhibits high rates of insertion/deletion and sequence divergence [20]. These features make $t r n H-p s b A$ highly suitable candidate plant barcode for species resolution. Later on, the nuclear ribosomal internal transcribed spacer (ITS) region considered as supplementary barcode, though China Plant Barcode of Life claimed ITS region had higher

${ }^{*}$ Corresponding author : taufan.ltd@gmail.com 
discriminatory power than plastid core barcodes [3], [18]. The ITS region has some limitations which prevent it from being a core barcode such as incomplete concerted evolution, fungal contamination and difficulties of amplification and sequencing [18]. Plastid gene large subunit of the ribulose-bisphosphate carboxylase gene $(r b c L)$ is of $1350 \mathrm{bp}$ in length and choice for DNA barcoding [4]. The maturase gene matK is about $1500 \mathrm{bp}$ long and located within the $\operatorname{trnK}$ gene encoding the tRNALys (UUU). Substitution rate of the matK gene is highest among the plastid genes [17]. Plastid gene matK can discriminate more than $90 \%$ of species in the Orchidaceae but less than $49 \%$ inthe nutmeg family [20], [27]. In another case, identification of 92 species from 32 genera using the matK barcode could achieve a success rate of $56 \%$ [12]. However, a recent study of the flora of Canada revealed $93 \%$ success in species identification with $r b c L$ and $m a t K$, while the addition of the trnH-psbA intergenic spacer achieved discrimination up to $95 \%$ [2]. The species discrimination was lower $(<50$ $\%$ ) for $r b c L+m a t K$ combination in the study of tropical tree species in French Guiana [13]. Lower discriminationwere reported in closest and complex taxa of Lysimachia, Ficus, Holcoglossum and Curcuma using $r b c L$ and $m a t K$ [39], [41], [22], [5]. The lowest discriminatory power was observed in closely related groups of Lysimachia with $r b c L$ (26.5-38.1\%), followed by matK (55.9-60.8\%) and combinations of core barcodes $(r b c L+m a t K)$ had discriminationof 47.1-60.8 \% [41]. Delineating mangrove species from putative hybridsusing morphological characters are always questionable. Putative hybrids were reported within the major generaof Rhizophora, Sonneratia and Lumnitzera and recentl in Bruguiera [10]. In the present study, we assessed mutation mangrove species using plastid coding loci $r b c L$ and $m a t K$ mangroves from coastal Cilacap, Central Java, Indonesia. This is our first steptowards DNA barcoding of mangroves based on plastid genes. Our study might be helpful towards mangrove conservation.

\section{Methods}

\subsection{Sample collection}

In the present study, leaf samples of 20 mangrove A. Ilifolicius were collected fromcoastal Cilacap, located on located on the west coast of Cilacap with geographical latitude of $8^{\circ} 35^{\prime} \mathrm{S}-8^{\circ} 48^{\prime} \mathrm{S}$ and longitude of $108^{\circ} 46^{\prime} \mathrm{E}$ $109^{\circ} 03^{\prime} \mathrm{E}$.

\subsection{DNA extraction}

High content of phenolics, latex, mucilage, secondary polysaccharides and metabolites in these plants make it a difficult system for nucleic acid and protein isolation from mangrove plants. Cetyl-trimethyl ammonium bromide (CTAB) protocol for DNA extraction from mangroves was modified. Leaf tissue was pulverized in liquid nitrogen and pulverized leaf sample $(0.2 \mathrm{~g})$ were mixed with CTAB buffer (20 mM EDTA; $1.4 \mathrm{M} \mathrm{NaCl} ; 2$ $\%$ PVP-30; $1 \% \beta$-mercaptoethanol; $10 \%$ SDS and $10 \mathrm{mg} / \mathrm{ml}$ proteinase $\mathrm{K}$ ). The suspension was incubated at $60{ }^{\circ} \mathrm{C}$ for $60 \mathrm{~min}$ with gentle mixing and centrifuged at $14,000 \mathrm{rpm}$ for $10 \mathrm{~min}$ at room temperature with equal volume of chloroform: isoamyl alcohol(24:1). The aqueous phase was transferred to a new tube and DNA was precipitated with 0.6 volume of cold isopropanol $\left(-20^{\circ} \mathrm{C}\right)$ and chilled $7.5 \mathrm{M}$ ammonium acetate followed by storing at $-20{ }^{\circ} \mathrm{C}$ for $1 \mathrm{~h}$. The precipitated DNA was centrifuged at $14,000 \mathrm{rpm}$ for $10 \mathrm{~min}$ at $4{ }^{\circ} \mathrm{C}$ followed by washing with $70 \%$ ethanol. DNA was finally dissolved in TE buffer $(10 \mathrm{mM}$ Tris- $\mathrm{HCl}, 1 \mathrm{mM}$ Na2EDTA, pH 8.0) and its quantity and quality was confirmed by agarose gel electrophoresis and nanodrop (Thermo Scientific, USA).

\subsection{PCR and sequencing}

Amplification of plastid genes ( $r b c L$ and $m a t K)$ was carried out in $50-\mu l$ reaction mixture containing $10-20 \mathrm{ng}$ of template DNA, $200 \mu \mathrm{M}$ of dNTPs, $0.1 \mu \mathrm{M}$ of each primers and 1 unit of Taq DNA polymerase (Thermo Scientific, USA). The reaction mixture was amplified in Bio-Rad (T100 model) thermal cycler with temperature profile for $r b c L\left(94{ }^{\circ} \mathrm{C}\right.$ for $4 \mathrm{~min} ; 35$ cycles of $94{ }^{\circ} \mathrm{C}$ for $30 \mathrm{~s}, 55^{\circ} \mathrm{C}$ for $30 \mathrm{~s}, 72{ }^{\circ} \mathrm{C}$ for $1 \mathrm{~min}$; repeated for 35 cycles, final extension $72{ }^{\circ} \mathrm{C}$ for $10 \mathrm{~min}$ ) and for $\operatorname{mat} K\left(94{ }^{\circ} \mathrm{C}\right.$ for $1 \mathrm{~min} ; 35$ cycles of $94{ }^{\circ} \mathrm{C}$ for $30 \mathrm{~s}, 50{ }^{\circ} \mathrm{C}$ for $40 \mathrm{~s}, 72{ }^{\circ} \mathrm{C}$ for $40 \mathrm{~s}$; repeated for 37 cycles, final extension $72{ }^{\circ} \mathrm{C}$ for $5 \mathrm{~min}$ ). The amplified products were separatedby agarose gel $(1.2 \%)$ electrophoresis and stainedwith ethidium bromide [35]. Two pair of universal primers $r b c L$ (rbcLa_F and $r b c L \mathrm{a}_{-} \mathrm{R}$ ) and $m a t K_{-}$390f and $m a t K_{-} 1326 \mathrm{r}$ were used for the amplification purpose [19], [5]. PCR amplification was performed using forward and reverse primers [3]. Primers used for DNA amplification of $r b c L$ and matK gene were $r b c L a_{-} \mathrm{f}$ : 5'ATGTCACCACAAACZAGAGACTAAAGC-3'and rbcL724 -r : 5'-“GTAAAATCAAGT CCACCRCG” -3'; matK_390-f : 5'- "CGATCTATTCATTCAATATTTC"-3' and matK_1326-r: 5' TCTÄGCACACGAAAGTCGAAGT-3'.

${ }^{*)}$ Corresponding author : taufan.ltd@gmail.com 


\section{Result and discusion}

3.1 Genetic Mutations of Mangrove A. Ilifoliciu susing Barcode DNA based on rbcL and matK Gen

The sequencing result of $r b c L$ produced an average of $580 \mathrm{bp}$ without any insertion, deletion and stop codon, whereas matK sequencing produced 712 bp with few insertion and deletions in the form of gaps without stop codon. Sequence alignment of rbcLand matK gene of $A$. ilifoliciususing Multalin (available at http://multalin.toulouse.inra.fr/multalin) showing different number and position of nucleotide (Picture 1 and Picture 2).
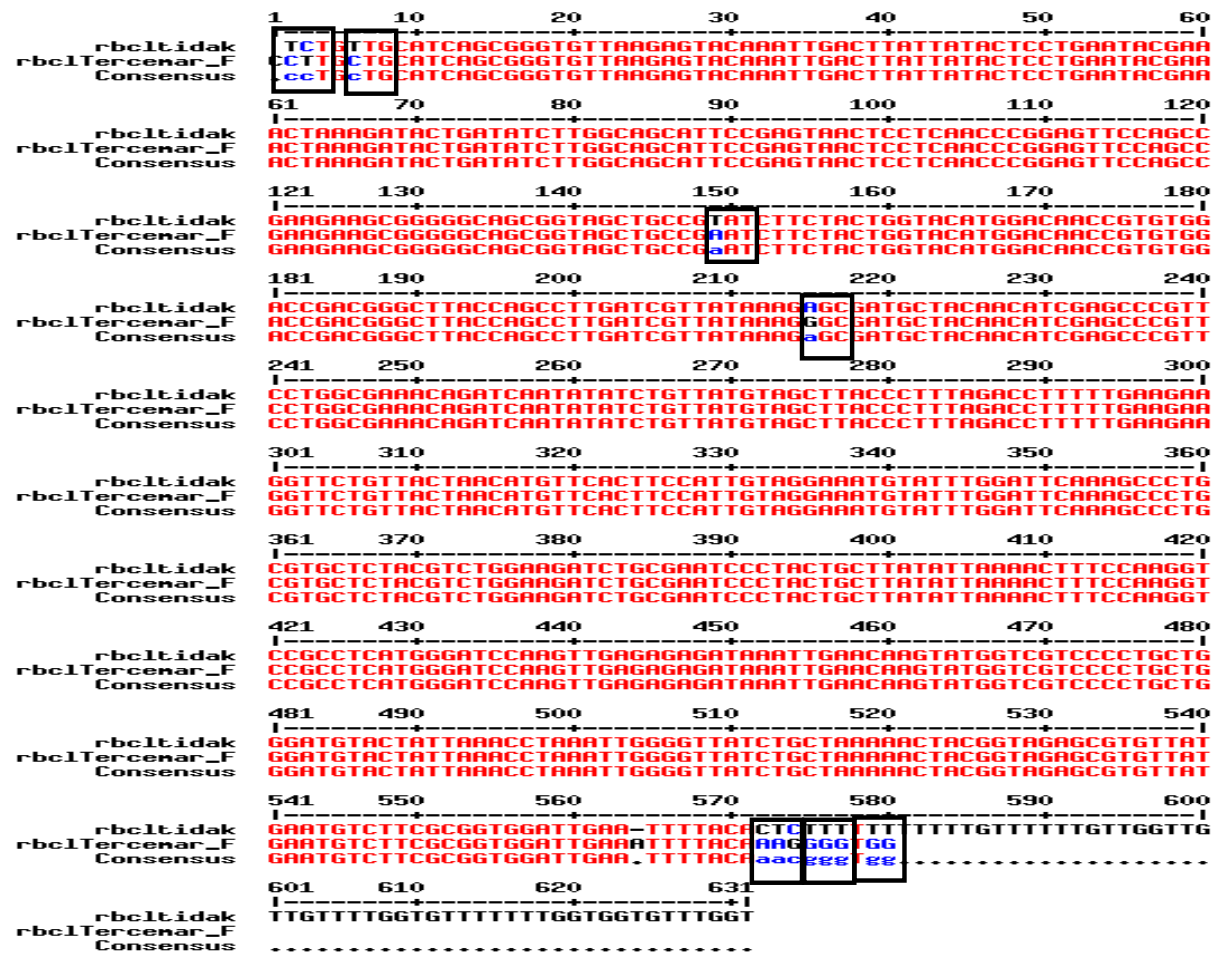

Fig. 1. Sequence alignment of $\mathrm{rbcL}$ gene of $A$. ilifoliciusbetween contaminated mangroves compared with uncontaminated mangrovesusing Multalin (available at http://multalin.toulouse.inra.fr/multalin)

${ }^{*}$ Corresponding author : taufan.1td@gmail.com 


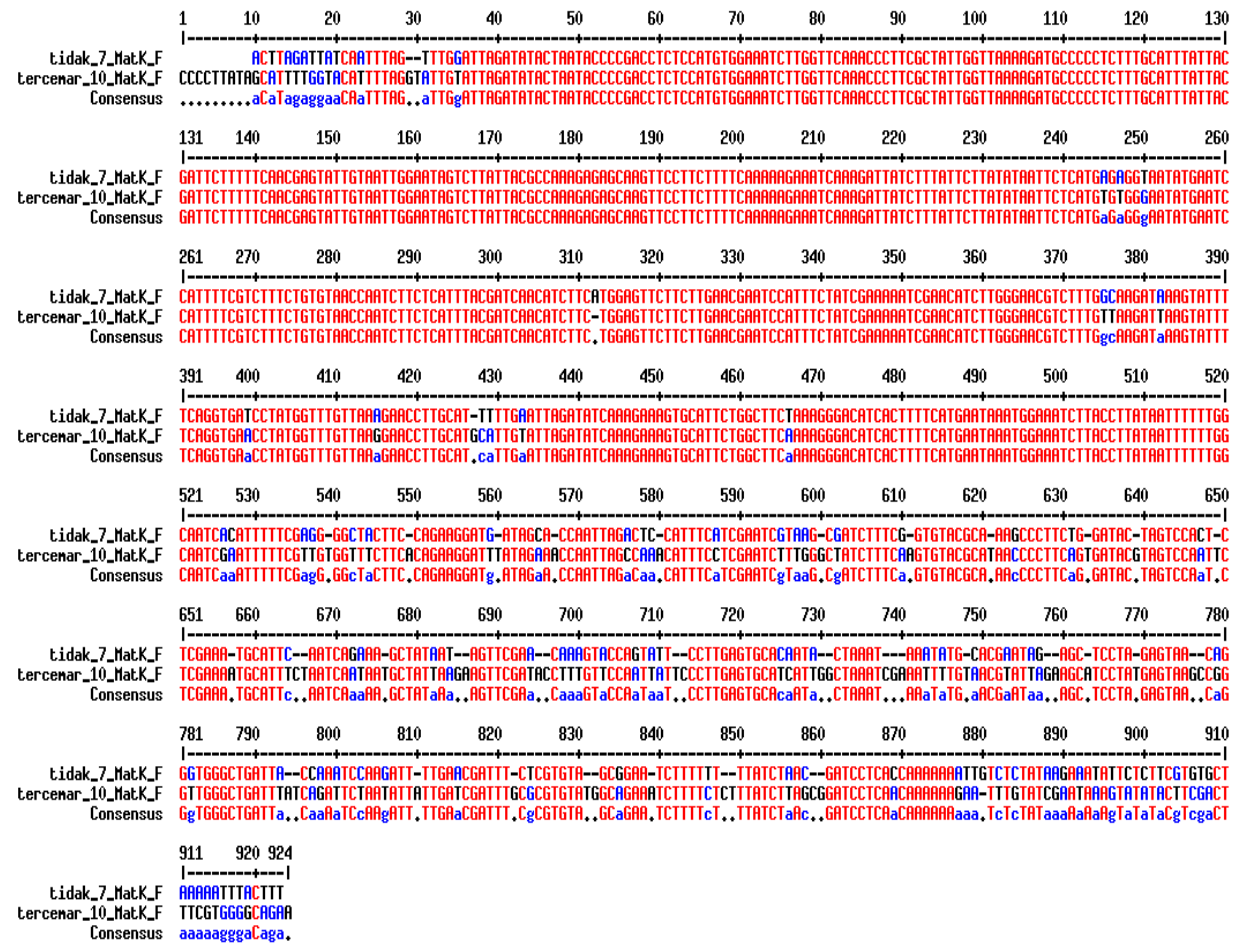

Fig. 2. Sequence alignment of matK gene of A. Ilifolicius between contaminated mangroves compared with uncontaminated mangrovesusing Multalin (available at http://multalin.toulouse.inra.fr/multalin)

Position of different nucleotides in species with the same or a different number of nucleotide difference was not the same in $\mathrm{rbcL}$ and matK at uncontaminated and contaminated location. The different of both nucleotides indicated that occure of mutation. The mutation of $A$. Ilifolicius based on rbcL gene has 7 mutation point. The mutation occurs at the locus 1-10 bp, $150 \mathrm{bp}, 215 \mathrm{bp}$ and 570-500 bp there are TCT-CTT, GTT-GCT, GTAGAA, GAG-GGG, ACT-AAA, CTT-GGG dan TTT-GTG. The mutation of A. Ilifolicius based on matK genes has 108 point mutation as seen in sequence alignment result. There are $10 \mathrm{bp}, 12 \mathrm{bp}, 14 \mathrm{bp}, 15 \mathrm{bp}, 16 \mathrm{bp}, 17 \mathrm{bp}$, 18 bp, 19 bp, 20 bp, 23 bp, 31 bp, 35 bp, 245 bp, 247 bp, 250 bp, 375 bp, 376 bp, 382 bp, 399 bp, 415 bp, 428 bp, 429 bp, 433 bp, 466 bp, 526 bp, 527 bp, 536 bp, 537 bp, 542 bp, 544 bp, 559 bp, 565 bp, 576 bp, 587 bp, 595 bp, 597 bp, 598 bp, 602 bp, 610 bp, 624 bp, 631 bp, 647 bp, 664 bp, 672 bp, 673 bp, 682 bp, 684 bp, 694 bp, 698 bp, 699 bp, 700 bp, 703 bp, 707 bp, 709 bp, 725 bp, 726 bp, 729 bp, 743 bp, 745 bp, 749 bp, 753 bp,756 bp, 757 bp, 779 bp, 782 bp, 793 bp, 797 bp, 798 bp, 800 bp, 803 bp, 806 bp, 815 bp, 824 bp, 835 bp, 846 bp, 856 bp, 858 bp, 869 bp, 877 bp, 878 bp, 879 bp, 882 bp, 884 bp, 888 bp, 889 bp, 890 bp, 892 bp, 894 bp, 896 bp, 898 bp, 900 bp, 902 bp, 904 bp, 906 bp, 907 bp, 908 bp, 911 bp, 912 bp, 913 bp, 914 bp, 915 bp, 916 bp, 917 bp, 918 bp, 919 bp, $921 \mathrm{bp}, 922 \mathrm{bp}$ and $923 \mathrm{bp}$.

To the best of our knowledge, current research is the first attempt of performing genetic mutation in mangrove A. ilifolicius based on DNA barcoding from Cilacap, Central Java, Indonesia using plastid core markers $r b c L$ and $m a t K$. The rbcL barcoding genes has differentiation 7 nucleotide sequences nucleotide that is $\mathrm{TCT} \rightarrow \mathrm{CTT}, \mathrm{GTT} \rightarrow \mathrm{GCT}, \mathrm{GTA} \rightarrow \mathrm{GAA}, \mathrm{GAG} \rightarrow \mathrm{GGG}, \mathrm{ACT} \rightarrow \mathrm{AAA}, \mathrm{CTT} \rightarrow \mathrm{GGG}$ dan TTT $\rightarrow$ GTG. The rbcL barcoding genes has differentiation 108 nucleotide sequence. The change of nucleotide bases caused converts the encoded amino acid caused by a point mutation [17]. The Point mutation is involves mutation the replacement of one base pairs (bases substitution), the one base at the DNA sequences replaced with different base. The mutation is the permanent change wich heredity in the genome (gene and nucleotid sequence) in some organism [1]. The gene coding caused of change nucleotid sequence without changed of amino acid (synonym mutation) [33], [34], [31] The change of nucleotide base in rbcL and matK gene maybe caused of long term anthropogenic pollution [40].

${ }^{*}$ Corresponding author : taufan.1td@gmail.com 


\section{Conclusions}

DNA barcoding can be used to detection of mutation in Acanthus ilifolicius. The mutation of A. Ilifolicius based on $\mathrm{rbcL}$ and matK gene has 7 and 108 mutation point. The change of nucleotide bases caused by a point mutation. The change of nucleotide base in $\mathrm{rbcL}$ and matK gene maybe caused of long term anthropogenic pollution.

This project was funded by BLU (Junior Lecture Research) Jenderal Soedirman University.

\section{References}

1. Alongi D.M. Environ Conserv. 29: 331-349 (2002)

2. Burgess KS, Fazekas AJ, Kesanakurti PR, Graham SW, Husband BC, Newmaster SG, Percy DM, Hajibabaei M, Barrett SCH. 20:8-12 (2011)

3. CBOL Plant Working Group. PNAS USA 106:12794-12797 (2009)

4. Chase MW. Ann Missouri Bot Gar 80:528-580 (1993)

5. Chen J, Zhao J, Erickson DL, Xia N, Kress WJ. Mol Ecol Resour 15:337-348 (2015)

6. Corpet F. Nucleic Acids Res 16:10881-10890 (1988)

7. Dereeper A, Guignon V, Blanc G, Audic S, Buffet S, Chevenet F, Dufayard J-F, Guindon S, Lefort V, Lescot M, Claverie JM, Gascuel O. Nucleic Acids Res 36:465-469 (2008)

8. Dereeper A, Guignon V, Blanc G, Audic S, Buffet S, Chevenet F, Dufayard J-F, Guindon S, Lefort V, Lescot M, Claverie JM, Gascuel O. Nucleic Acids Res 36:465-469 (2008)

9. Dong W, Liu J, Yu J, Wang L, Zhou S. PLoS ONE 7:e35071 (2012)

10. Duke N, Meynecke J, Dittmann S, Ellison A, Anger K, Berger U, Cannicci S, Diele K, Ewel K, Field C. Science. 317: 41-42 (2007)

11. Duke NC. University of Queensland and Norman C. Duke, Brisbane. (2006)

12. Fazekas AJ, Burgess KS, Kesanakurti PR, Graham SW, Newmaster SG, Husband BC, Percy DM, Hajibabaei M, Barrett SCH. PLoS ONE 3:e2802. (2008)

13. Gonzalez MA, Baraloto C, Engel J, Mori SA, Pétronelli P. PLoS ONE 4:e7483 (2009)

14. Hebert PDN, Cywinska A, Ball SL, deWaard JR. Proceedings of the Royal Society of London, Series B 270: 313-321 (2003)

15. Hebert PDN, Gregory TR. Systematic Biology 54: 852-859 (2005)

16. Hebert PDN, Ratnasingham S, DeWaard JR. Proceedings of the Royal Society B Biological Sciences 270:S96-S99 (2003b)

17. Hilu KW, Borsch T, Muller K. Am J Bot 90:1758-1776 (2003)

18. Hollingsworth ML, Clark A, Forrest LL. Mol Ecol Resour 9:439-457 (2009)

19. Kress J, Erickson DL. PLoS ONE 2:e508 (2007)

20. Kress WJ, Erickson DL, Swenson NG. PLoS ONE 5:e15409. (2010)

21. Kuzmina ML, Johnson KL, Barron HR, Hebert PDN. BMC Ecol 12:25 (2012)

22. Li HQ, Chen JY, Wang S, Xiong SZ. Mol Ecol Resour 12:783-790 (2012)

23. Li X, Yang Y, Henry RJ, Rossetto M, Wang Y, Chen S. Biol Rev 90:157-166 (2015)

24. Lissy KP and Simon TK. J. Mari. Biol. Ass. India. 43 :222-227 (2011)

25. Little DP, Stevenson DW. Cladistics 23:1-21 (2007)

26. Manojit Bhattacharya, Ashish Ranjan Sharma, Bidhan Chandra Patra, Garima Sharma, Eun-Min Seo, Ju-Suk Nam, Chiranjib Chakraborty \& Sang-Soo Lee. Mitochondrial DNA Part A, 27:4, 2744-2752 (2011)

27. Newmaster SG, Fazekas AJ, Steeves RAD, Janovec J. Mol Ecol Resour 8:480-490 (2008)

28. Polidoro BA, Carpenter KE, Collins L, Duke NC, Ellison AM. PLoS ONE 5: e10095 (2010)

29. Purushothaman N, Newsmaster SG, Ragupathy S, Stalin N, Suresh D, Arunraj DR, Gnanasekaran G, Vassou SL, Narasimhan D, Parani M. Genet Mol Res 13:2959-2968 (2014)

30. Purushothaman N, Newsmaster SG, Ragupathy S, Stalin N, Suresh D, Arunraj DR, Gnanasekaran G, Vassou SL, Narasimhan D, Parani M. Genet Mol Res 13:2959-2968 (2014)

31. Ragavan P, Saxena A, Mohan P.M, Jayaraj R.S.C, Ravichandran K. J.Biodiversitas.Vol. 16 (2), page 225-237 (2005)

32. Ross HA, Murugan S, Li WLS. Syst Biol 57:216-230 (2008)

33. Saadullah, Khan ZUD, Ashfaq M, Zaib u Nisa. Journal of Biodiversity and Environmental Sciences 8:175_186. (2016)

34. SaddeA.A, Rahul Arvind Jamdade, Kundan Kumar. SpringerPlus 5:1554 (2016)

35. Sambrook J, Fritsch EF, Maniatis T. pp 5.1-5.17 (1989)

36. Valiela I, Bowen J.L, York J.K. Bioscience. 51: 807-815 (2011)

${ }^{*)}$ Corresponding author : taufan.ltd@gmail.com 
37. Wang WQ, Wang M. The Mangroves of China. Science Press, Beijing [Chinese] (2007)

38. Widyastuti A, Yani E, Nasution KE, Rochmatino. Biodiversitas. 19 (1) 246-252 (2011)

39. Xiang XG, Hu H, Wang W, Jin XH. Mol Ecol Resour 11:1012-1021 (2011)

40. Xu, S., He Z.,Zhang, Z., Guo, Z., Guo, W., Lyu, H., Li, L., Yang, M., Du, Z., Huang, Y.,Zhou, R., Zhong, C., Boufford, D.E., Lerdau, M., Wu, C.i., Duke, N.C., Shi, S. National Science Review. (2017)

41. Zhang CY, Wang FY, Yan HF, Hao G, Hu CM, Ge XJ. Mol Ecol Resour 12:98-108 (2012) 